\title{
Badania porównawcze nad totalitaryzmem nazistowskim i stalinowskim w historiografii zachodniej. Uwagi w związku z książką Stalinizm i nazizm. Porównanie dyktatur, red. I. Kershaw, M. Lewin, Harmonia Universalis, Gdańsk 2015, ss. 437
}

Fenomen dwudziestowiecznych państw totalitarnych i autorytarnych stanowi istotne zagadnienie badawcze w zachodnich naukach historycznych, politycznych, filozoficznych i prawnych. Już od $1917 \mathrm{r}$. analizowano zagrożenia płynące dla cywilizacji zachodniej ze strony nihilistycznego bolszewizmu sowieckiego. W przedwojennej Europie istotnym problemem okazał się szybko wzrost tendencji autorytarnych i faszystowskich (Włochy, Europa Środkowo-Wschodnia, Hiszpania). Nową jakość stanowiła III Rzesza A. Hitlera, zaliczana do dyktatur o charakterze otwarcie totalitarnym.

Badania nad bolszewizmem, faszyzmem i nazizmem były prowadzone w przedwojennym świecie zachodnim przede wszystkim przez emigrantów wschodnioeuropejskich, a po 1933 r. również przez wybitnych emigrantów niemieckich ${ }^{1}$. Tworzyli oni początki nauk sowietologicznych i badań dotyczących fenomenu totalitarnego. W gronie tym był m.in. M. Bierdiajew (analizujący sowietyzm w kontekście filozoficznym, historiozoficznym i religijnym), M. Karpowicz, M. Florinsky, B. Souvarine, W. Gurian, M. Horkheimer, H. Rauschning, H. Marcuse, J. Schumpeter, F. Borkenau, E. Fraenkel, S. Neumann $^{2}$. Swoje rozważania dotyczące dyktatur opierali oni w znacznym stop-

${ }^{1}$ M. Filipowicz, Emigranci i jankesi. O amerykańskich historykach Rosji, Lublin 2007; M. Raeff, Russia Abroad. A Cultural History of the Russian Emigration 1919-1939, New York-Oxford 1990; R. Williams, Culture in exile: Russian emigres in Germany 1881-1941, London 1972; C. Aucheyer, L. Savicky, Russia Abroad. Prague and the Russian Diaspora 1918-1939, New Heaven 2004; Emigracja rosyjska. Losy i idee, red. R. Backer, Z. Karpus, Łódź 2002; L. Suchanek, Emigracja rosyjska XX wieku, [w:] Rosjoznawstwo, red. L. Suchanek, Kraków 2004.

${ }_{2}^{2}$ M.in. M. Styczyński, Umiłowanie przyszłości albo filozofia spraw ostatecznych, Łódź 2001; J. Krasicki, Bierdiajew i inni, Warszawa 2012; L. Cain, Berdiaev an Russie, Paris 1962; O. Clarke, Introduction to Berdyaev, London 1950; F. Nucho, Berdyaev's Philosophy, Garden City 1966; G. Grzmot-Bilski, Bierdiajew i problem wolności, Bydgoszcz 2010, s. 202-217; E. Borowska, 
niu na osobistych doświadczeniach wynikających z życia w reżimach niedemokratycznych. O zagrożeniach płynących z bolszewizmu i nazizmu pisali również m.in. M. Fainsod, A. Cobban, B. Pares, tworzący sowietologiczne kierunki badawcze na znanych uczelniach zachodnich ${ }^{3}$.

Istotną rolę w badaniach nad totalitaryzmem odgrywali przed wojną Polacy, szczególnie skupieni wokół wileńskiego Instytutu Naukowo-Badawczego Europy Wschodniej (m.in. W. Sukiennicki, S. Swianiewicz, F. Ancewicz) ${ }^{4}$. Wielu badaczy dokonywało porównania reżimów faszystowskiego, nazistowskiego i bolszewickiego, wskazując na pewne podobieństwa (jednoosobowe dyktatury oparte na masowej partii i oficjalnie promowanej ideologii, system rządów policyjnych i szeroko stosowanego terroru, kontrola nad społeczeństwem, sztuką i mediami, etatystyczne doktryny ekonomiczne $)^{5}$.

$\mathrm{W}$ nauce zachodniej przed $1939 \mathrm{r}$. tworzono pierwsze teorie totalitaryzmu jako specyficznego nowego rodzaju ustroju polityczno-prawnego i nowego rodzaju ideologii politycznej. Wskazywano na niszczenie w ramach systemu totalitarnego wartości cywilizacji chrześcijańskich oraz zachodnich standardów prawnych. Totalitaryzm porównywano do dawnych dyktatur, tyranii, autokracji i absolutyzmów, wskazując na nowatorską rolę ideologii w stałym mobilizowaniu szerokich mas społecznych. Szukano związków genetycznych między bolszewizmem i nazizmem, wskazując na różnorodne obustronne

Marks i Rosja, [w:] Wokót Leontjewa i Bierdiajewa, Warszawa 2001; C. Gottlieb, Dilemmas of Reaction in Leninist Russia. The Christian Response to the Revolution in the Works of N. A. Berdyaev 1917-1924, Odense 2003; Boris Souvarine et la critique sociale, Paris 1990; J. Panne, Boris Souvarine, Paris 1993; J. Arnason, Totalitarianism and Modernity: F. Borkenau's ,Totalitarian Enemy" as a Source of Sociological Theorizing on Totalitarianism, [w:] The Totalitarian Paradigm after The End of Communism, red. A. Siegel, Amsterdam-Atlanta 1998, s. 151-179; M. Karpovich, Imperial Russia 1801-1917, New York 1932; M. Florinsky, Toward an Understanding of the USRR, New York 1939; W. Gurian, Der Bolschewismus, Freiburg 1931; E. Fraenkel, The Dual State, New York 1941; J. Schumpeter, Capitalism, Socialism and Democracy, New York 1962.

${ }^{3}$ D. Galton, Sir Bernard Pares and Slavonic Studies in London University 1919-1939, „Slavonic and East European Review”, 1968, vol. 46; B. Pares, A History of Russia, New York 1926; idem, The Fall of Russian Monarchy, London 1939; A. Cobban, Dictatorship. Its History and Theory, London 1939.

${ }^{4}$ M. Kornat, Bolszewizm, totalitaryzm, rewolucja, Rosja: początki sowietologii i studiów nad systemami totalitarnymi w Polsce (1918-1939) t. 1 i 2, Kraków 2003-2004; idem, Polska szkoła sowietologiczna 1930-1939, Kraków 2003; idem, Instytut Naukowo-Badawczy Europy Wschodniej w Wilnie (1930-1939) i jego wkład w rozwój polskiej sowietologii, „,Kwartalnik Historyczny”, 2000, nr 3, s. 152-199; idem, Sowietologia i studia wschodoznawcze w Polsce międzywojennej, „Zeszyty Historyczne" (ZH), 2002, t. 140, s. 39-101; idem, Interpretacje bolszewizmu i systemów totalitarnych $w$ Polsce (1918-1939), ZH, 2003, z. 146, s. 3-45; R. Potocki, Instytut Naukowo-Badawczy Europy Wschodniej w Wilnie (1930-1939), „Przegląd Zachodni”, 2000, nr 2, s. 211-219.

${ }^{5}$ H. Heller, Europa und der Faschismus, Berlin 1929; E. Forsthoff, Der totale Staat, Hamburg 1933; G. Megano, Mussolini in the Making, Boston-New York 1938; A. Rossi, The Rise of Italian Fascism 1918-1922, London 1938; F. Borkenau, The Totalitarian Enemy, London 1940; W. McGovern, From Luther to Hitler: the history of fascist - nazi political phliosophy, Cambridge 1941; S. Neumann, Permanent Revolution, New York-London 1942; L. Bernhard, System Mussoliniego, oprac. A. Peretiatkowicz, Poznań 1925. 
inspiracje i dążenie do wprowadzania analogicznych rozwiązań polityczno-prawnych przez Hitlera i Stalina (np. w zakresie masowej propagandy ideologicznej oraz rozbudowanego systemu terroru stosowanego wobec ,wroga klasowego" czy „wroga rasowego").

Do starcia dwóch totalitaryzmów doszło w okresie II wojny światowej, kiedy kraje zachodnie z powodów pragmatycznych popierały politykę J. Stalina. Po 1945 r. kwestia III Rzeszy była definitywnie zamknięta, ale świat zachodni rozpoczął politykę konfrontacji z ZSRR i blokiem wschodnim w ramach polityki zimnowojennej, trwającej praktycznie do $1989 \mathrm{r}$.

W okresie powojennym napisano setki prac o faszyzmie i nazizmie analizujących te zbrodnicze fenomeny w kontekście badań z zakresu historii, filozofii, politologii, prawa, socjologii czy psychologii społecznej. Tworzono różne teorie dotyczące genezy i rozwoju nazizmu i faszyzmu, często bardzo sprzeczne ${ }^{6}$. Spory dotyczyły istoty nazistowskiego państwa i prawa oraz oceny rzeczywistej roli jednoosobowej dyktatury Hitlera i jego wpływu na

${ }^{6}$ M. Zmierczak, Spory o istotę faszyzmu. Dzieje i krytyka, Poznań 1988. Istotna literatura przedmiotu powstawała przede wszystkim w Stanach Zjednoczonych, Wielkiej Brytanii, we Włoszech i w RFN, zob. m.in. F. Neumann, Behemot. The Strutcure and Practice of National Socialism 1933-1944, New York 1963; E. Kogon, Der SS-Staat, Stokholm 1947; F. Meinecke, Die deutsche Katastrophe, Wiesbaden 1949; L. Schapiro, Liberalism and the Challenge of Fascism, New York 1949; H. Buchheim, Das Dritte Reich, Munchen 1960; W. Hofer, Die Diktatur Hitlers, Konstanz 1960; G. Ritter, Das deutsche Problem, Munchen 1962; E. Nolte, Der Faschismus in seiner Epoche, Munich 1963; R. de Felice, Mussolini il rivoluzionairo, 1883-1920, Turyn 1965; E. Nolte, Three Faces of Fascism, New York 1965; L. Struzo, Italia e fascismo, Bolonia 1965; M. Bronsztad, German National Socialism 1919-1945, Santa Barbara 1966; T. Abel, The Nazi Movement: Why Hitler Came to Power, New York 1966; F. Carsten, The Rise of Fascism, London 1967; R. O' Neill, The German Army and the Nazi Party 1933-1939, New York 1967; A. Gregor, The Ideology of Fascism, New York 1969; K. Bracher, The German Dictatorship, New York 1970; B. Smith, H. Himmler: a nazi in the making 1900-1926, Stanford 1971; M. Ledeen, Universal Fascism. The Theory and Practice of the Fascism International 1928-1936, New York 1972; M. Kele, Nazis and Workers, Chapell Hill 1972; W. Ebenstein, Fascist Italy, New York 1973; P. Hayes, Fascism, London 1973; J. Fest, Hitler, New York 1974; R. de Felice, Il fascismo, Roma 1974; R. Saage, Faschismustheorien, Munchen 1976; W. Reich, The mass psychology of fascism, New York 1976; R. Waite, The Psychopatic God. Adolf Hitler, New York 1977; J. Stern, Hitler, München 1978; M. Michaelis, Mussolini and the Jews, Oxford 1978; D. Irving, Hitlers Weg zum Krieg, München 1979; International Fascism, red. G. Mosse, London 1979; A. Gregor, Young Mussolini and the Intellectual Origins of Fascism, Berkeley 1979; H. Glaser, Das Dritte Reich, Freiburg 1979; S. Payne, Fascism: comparison and definition, London 1980; W. Shirer, The rise and fall of the Third Reich, New York 1981; European Fascism, red. S. Woolf, London 1981; G. Grimm, Der Nationalsozialismus: Programm und Verwirklichung, Munchen 1981; M. Kater, The Nazi Party: A Social Profile of Members and Leaders 1919-1945, Cambridge 1983; I. Kershaw, Public Opinion and Political Dissent in the Third Reich 1933-1945, Oxford 1984; D. Penkert, Inside Nazi Germany. Conformity, Opposition and Racism in Everyday Life, New Haven 1987; I. Kershaw, The „Hitler Myth”: Image and Reality in the Third Reich, Oxford 1987; T. Schulte, The German Army and Nazi Policies in Occupied Russia, New York 1989; J. Fest, Oblicze Trzeciej Rzeszy, Warszawa 1970; G. Mosse, Kryzys ideologii niemieckiej. Rodowód intelektualny III Rzeszy, Warszawa 1972; R. Manvell, Goebbels, Warszawa 1972; P. Monelli, Mussolini, Warszawa 1973; A. Bullock, Hitler: studium tyranii, Warszawa 1975; R. de Felice, Interpretacje faszyzmu, Warszawa 1976; J. Heydecker, J. Leeb, Trzecia Rzesza w świe- 
$\mathrm{NSDAP}^{7}$. Część badaczy (tzw. intencjonaliści) skupiało się przede wszystkim na akcentowaniu znaczenia woli i osobowości samego Hitlera (m.in. K. Bracher, K. Hildebrandt, A. Hillgruber ${ }^{8}$. Zwolennicy teorii „strukturalizmu” zwracali natomiast uwagę przede wszystkim na funkcjonowanie całego systemu partyjno-państwowego III Rzeszy, albowiem ich zdaniem niezależnie od dyktatorskiej władzy Hitlera wiele organów państwowych czy partyjnych miało pewną autonomię działania (M. Broszat, H. Mommsen, R. Bollmus) ${ }^{9}$. Swoistą syntezę tych poglądów proponował I. Kershaw ${ }^{10}$. H. Arendt podkreślała, że nazistowski dynamiczny ruch społeczny poprzedzał powstanie samego dyktatorskiego państwa ${ }^{11}$. H. Mommsen wskazywał natomiast na proces postępującej radykalizacji działania aparatu III Rzeszy, prowadzący do nieuchronnej autodestrukcji ${ }^{12}$.

Genezy nazizmu dopatrywano się m.in. w tradycji niemieckiego idealizmu i romantyzmu (G. Mosse, H. Plessner, L. Krieger), akcentując teorię ,wyjątkowego rozwoju historycznego Niemiec"13. Wskazywano na podobieństwa między nazizmem a bolszewizmem (Z. Sternhell, L. Greenfeld, E. Nolte) ${ }^{14}$.

$\mathrm{R}$. Tokarczyk dokonał interesującego zestawienia głównych koncepcji genezy $\mathrm{i}$ istoty faszyzmu (nazimu) tworzonych w ramach powojennych zachodnich nauk społecznych, wyróżniając teorię historyczną (faszyzm jako wynik autorytarnej i militarnej niemieckiej tradycji historycznej), teorię etyczną (faszyzm jako rezultat głębokiego kryzysu moralnego cywilizacji zachodniej), teorię psychologiczną (autorstwa E. Fromma i T. Adorno), teorię socjologiczną (faszyzm jako forma ,gwałtownego przejścia od społeczeństwa tradycyjnego do społeczeństwa industrialnego") oraz teorię politologiczną (zastąpienie liberalnej demokracji parlamentarnej formą rządów opartych na tyranii) ${ }^{15}$.

Badania nad hitleryzmem były dopuszczalne po $1945 \mathrm{r}$. w krajach bloku wschodniego, chociaż podlegały one istotnym ograniczeniom politycznym i cenzuralnym ${ }^{16}$. Nazizm i hitleryzm interpretowano przede wszystkim w ka-

tle Norymbergii, Warszawa 1979; Kościól, katolicy i narodowy socjalizm, red. K. Gotto, K. Repqen, Warszawa 1983; R. Gruneberger, Historia społeczna III Rzeszy, Warszawa 1987.

${ }^{7}$ M.in. M. Zmierczak, Spory historyków i politologów o ustrój III Rzeszy, [w:] Studia z historii ustroju i prawa, red. H. Olszewski, Poznań 2002, s. 479-487.

${ }^{8}$ Ibidem, s. 483.

9 Ibidem, s. 484.

${ }^{10}$ Ibidem, s. 485.

11 Ibidem, s. 486.

12 Ibidem.

13 Z. Krasnodębski, Intelektualne źródła totalitaryzmu, [w:] Totalitaryzm a zachodnia tradycja, red. M. Kuniński, Kraków 2006, s. 94-95.

${ }^{14}$ Ibidem, s. 96-97.

15 R. Tokarczyk, Współczesne doktryny polityczne, Kraków 2000, s. 357-360.

${ }_{16}$ M.in. W. Kozub-Ciembroniewicz, Interpretacje faszyzmu w Polsce (1945-1989), „Studia nad Faszyzmem i Zbrodniami Hitlerowskimi" (SFZH), 1995, s. 63-100; F. Ryszka, Państwo stanu wyjątkowego. Rzecz o systemie państwa i prawa Trzeciej Rzeszy, Wrocław-Warszawa-Kraków 
tegoriach marksistowskiej teorii walki klas społecznych. Za państwo totalitarne uważano głównie III Rzeszę, odrzucając z oczywistych powodów politycznych porównywanie jej do ZSRR Stalina. Tego typu zabiegi dokonywane W sowietologii zachodniej uznawano za dyktowane czynnikami politycznymi i ideologiczno-propagandowymi.

Po II wojnie światowej sowietologia rozumiana w sensie szerokim (obejmująca nauki polityczne, socjologię, historię, filozofię, psychologię społeczną, prawo i ekonomię) rozwijała się przy wielu czołowych uniwersytetach i innych ośrodkach badawczych, m.in. w USA, Francji, Wielkiej Brytanii i RFN ${ }^{17}$. W wielu tych instytucjach badawczych czołową rolę odgrywali emigranci wschodnioeuropejscy, w tym Polacy ${ }^{18}$. Twórca szwajcarskiego ośrodka

1964; M. Maciejewski, Prawo, państwo i polityka w poglądach Franciszka Ryszki, [w:] Wybitni prawnicy na przestrzeni wieków, red. M. Marszał, J. Przygodzki, Wrocław 2006; W. Kozub-Ciembroniewicz, Faszyzm i niedemokratyczne systemy władzy w twórczości naukowej Franciszka Ryszki, SFZH, 2004; H. Olszewski, Karola Joncy „, Studia nad Faszyzmem i Zbrodniami Hitlerowskimi”, „Czasopismo Prawno-Historyczne” (CPH), 2008, z. 1, s. 291-298; W. Wichert, Ustrój wodzowski Trzeciej Rzeszy. Z badań nad tekstami we wrocławskim roczniku , Studia nad Faszyzmem i Zbrodniami Hitlerowskimi”, CPH, 2010, z. 2, s. 383-407.

${ }^{17} \mathrm{Na}$ temat powojennego rozwoju badań sowietologicznych w świecie zachodnim oraz licznych kontrowersji dotyczących ich przedmiotu, metodologii i podporządkowania celom polityki zimnowojennej zob. m.in. The State of Soviet Union, red. W. Laquer, L. Labedz, Cambridge 1965; Anatomy of Anticommunism, New York 1969; Communist Studies and Social Sciences. Essays on Methodology and Empirical Theory, Chicago 1969; P. Hassner, Western European Perceptions of the USSR, „Deadalus”, 1979; Philosophical Sovietology: the persuit of a science, H. Dahm, T. Blakeley, G. Kline, Boston 1988; D. Engerman, Know your enemy: the rise and fall of America's Soviet experts, New York 2009; Post-Communist Studies and political science: methodology and empirical theory in Sovietology, red. F. Fleon, E. Hoffmann, Boulder 1993; A. Janos, Social Science, Communism and the Dynamics of Political Change, „World Politics”, 1991, nr 10, s. 81-112; G. Breslauer, In Defence of Sovietology, „Post-Soviet Affairs”, 1992, nr 7-8, s. 197-238; Rethinking the Soviet collapse: sovietology, the death of communism and the new Russia, red. M. Cox, LondonNew York 1991; M. Burawoy, The End of Sovietology and the Renaissance of Modernization Theory, „Contemporary Sociology”, 1992, t. 21; Post-Communist Studies and political science: methodology and empirical theory in Sovietology, red. F. Fleon, E. Hoffmann, Boulder 1993; M. Cox, The End of the USSR and the Collapse of Soviet Studies, „Coexistence”, 1994, t. 31; D. Lieven, Western Scholarship on the Rise and Fall of the Soviet Regime, „Journal of Contemporary History”, 1994, t. 29; A. Walicki, Interpretacje i diagnozy, „Przegląd Polityczny”, 2006, nr 76; J. Karpiński, Lekcja anatomii (makrosocjologia i sowietologia), [w:] idem, ABC polityki, Warszawa 1997; A. Garlicka, $Z$ badań nad Rosja i Europa Środkowo-Wschodnia w Stanach Zjednoczonych, [w:] Powrót do historii. Europa Środkowa i Wschodnia w historiografii, red. W. Balcerak, Warszawa 1994; R. Byrnes, A History of Russian and East European Studies in the United States, Lanham 1994.

${ }_{18}$ M.in. A. Bosiacki, Udziat polskich uczonych poza granicami kraju w tworzeniu kierunków sowietologii po drugiej wojnie światowej, SFZH, 2011, s. 329-240; R. Habielski, Humanistyka polska poza krajem (1945-1989), [w:] Humanistyka polska w latach 1945-1990, red. U. Jakubowska, J. Myśliński, Warszawa 2006; Tajny oręż czy ofiary zimnej wojny? Emigracje polityczne z Europy Środkowej i Wschodniej, red. S. Łukasiewicz, Lublin-Warszawa 2010; Paryż, Londyn, Monachium, Nowy Jork. Powrześniowa emigracja niepodległościowa na mapie kultury nie tylko polskiej, red. V. Wejs-Milewska, E. Rogalewska, Białystok 2009; A. Nowak, Czy istnieje „polska szkoła sowietologii"? Przypadki Leopolda Eabędzia, Adama Ulama i Richarda Pipesa, [w:] idem, Ofiary, imperia i historycy: studium przypadków (od XVIII do XXI w.), Kraków 2009. 
sowietologicznego J.M. Bocheński apelował o tworzenie rzetelnej metodologii badawczej w zakresie sowietologii i nieuleganie licznym naciskom politycznym ${ }^{19}$. W ramach badań sowietologicznych porównywano poszczególne państwa i systemy komunistyczne ${ }^{20}$.

Sowietolodzy i filozofowie analizowali wnikliwie doktryny marksizmu-leninizmu, uznając słusznie, że bardzo wielkie znaczenie przypisywano w reżimie sowieckim kwestiom ideologicznym (w tym gronie był m.in. J. Talmon, W. Gurian, K. Popper, I. Berlin, Z. Jordan, G. Wetter, S. Hook, S. Avineri, J. Plamenatz, G. Lichtheim, A. Meyer oraz polscy emigranci - L. Kołakowski, M. Hirszowicz i A. Walicki) ${ }^{21}$. Leninizmowi zarzucano m.in. radykalne odejście od wielu twierdzeń samego Marksa w celu dostosowywania jego „proroctw” do rzeczywistości sowieckiej. Uznawano marksizm-leninizm za rodzaj szkodliwej „świeckiej religii” lub za kolejny nurt filozoficznej utopii, prowadzącej ostatecznie do zbrodniczych skutków. Odmawiano leninizmowi miana nauki w rozumieniu zachodnim, opartej na logice i empiryzmie (K. Popper, J. Bocheński ${ }^{22}$.

19 G. Kucharczyk, Polska myśl polityczna po roku 1939, Dębogóra 2009, s. 46-49; A. Bosiacki, Udziat polskich..., s. 332-334; R. De George, The Critique of Marxist Philosophy: 1956-1981, [w:] Contemporary Marxism. Essays in Honor of J. M. Bocheński, Dordrecht-Boston 1984; J. Bocheński, Wspomnienia, Kraków 1994; A. Bosiacki, Śmierć ostatniego sowietologa? Koncepcje sowietologiczne śp. Ojca Profesora Innocentego Bocheńskiego, „Przegląd Humanistyczny”, 1997, nr 1; A. Rzegocki, Antytotalitaryzm zintegrowany Józefa Marii Bocheńskiego, SFZH, 2011, s. 493-503; J. Parys, „Dlaczego antykomunizm?” Ojciec Bocheński jako sowietolog, „Arcana”, 2005, nr 1-2; L. Godek, Partia komunistyczna jako ,,ideologia w akcji”. Wokót koncepcji ideologii komunistycznej. Rekonstrukcja koncepcji J.M. Bocheńskiego, [w:] Obrazy PRL. O konceptualizacji realnego socjalizmu w Polsce, red. K. Brzechczyn, Poznań 2008; J. Kozak, Józef Bocheński. W poszukiwaniu racjonalnego ładu świata, „Przegląd Filozoficzny”, 1998, nr 1; M. Styczyński, Sowietologia fryburska, „Archiwum Historii Filozofii i Myśli Społecznej”, 1999, t. 44.

${ }^{20}$ M.in. P. Hollander, Totalitarianism and the Comparative Study of Communism, „Slavic Review” 1967, t. XXVI, z. 2; A. Meyer, The Comparative Study of Communist System, „Slavic Review”, 1967, t. XXVI, z. 1; P. Shoup, Comparing Commmunist Nations: Prospects for an Empirical Approach, „American Political Science Review”, 1968, t. LXII, nr 1; Communist Party - States. Comparative and International Studies, red. J. Triska, New York 1969; J. Montias, Types of Communist Economic Systems, [w:] Change in Communist Systems, red. C. Johnson, Stanford 1970; W. Welsh, Toward an Empirical Typology of Socialist Systems, [w:] Comparative Socialist Systems, red. C. Mesa-Lago, C. Beck, Pittsburgh 1975.

${ }^{21}$ A. Walicki, I. Berlina intelektualna historia Rosji, „Przegląd Polityczny”, 2002, nr 54; M. Bankowicz, Krytycy marksizmu, Kraków 2014; Z. Jordan, Philosophy and Ideology. The Development of Philosophy and Marxism - Leninism in Poland since The Second World War, Dordrecht 1963; L. Kołakowski, Glówne nurty marksizmu. Powstanie - rozwój - rozkład, Paryż 1976-1978.

${ }^{22}$ K. Popper, Nędza historycyzmu, Warszawa 1987; idem, Spoleczeństwo otwarte i jego wrogowie, Warszawa 1987; J. Baudouin, La philosophie politique de Karl Popper, Paris 1994; I. Jarrie, S. Pralong, Popper's Open Society after 50 Years: The Continuing Relevance of K. Popper, London 1999; B. Magee, Popper, Warszawa 1998; E. Pietruska-Madej, Wiedza i czlowiek. Szkice o filozofii K. Poppera, Warszawa 1997; W. Wątroba, Socjologia i fallibilizm, Wrocław 1996; W. Słomski, Trzy światy: szkice o filozofii K. R. Poppera, Warszawa 2001, s. 131-146; A. Jabłoński, Budowanie spoleczeństwa wiedzy. Zarys teorii spolecznej K.R. Poppera, Lublin 2006; idem, Status 
Sowietolodzy zachodni spierali się o genezę i rozwój procesu rewolucji bolszewickiej ${ }^{23}$. Zwolennicy marksizmu (I. Deutscher, V. Serge, L. Trocki) postrzegali rewolucję 1917 r. jako zjawisko pozytywne, które zostało „zdradzone" przez dyktatorskie zapędy Stalina, uznawanego przez nich za swoistego kontrrewolucjonistę ${ }^{24}$. W ramach tzw. nurtu rewizjonistycznego badacze rozwijali tezy o wydarzeniach 1917 roku jako rzeczywistej rewolucji społecznej popieranej przez rosyjskich chłopów i robotników (m.in. L. Haimson, A. Rabinovitch, E. Carr, R. Suny, R. Tucker, S. Fitzpatrick, M. Lewin, S. Cohen) ${ }^{25}$.

teoretyczny i funkcja techniczna wiedzy o społeczeństwie. Wokół myśli K.R. Poppera i J.M. Bocheńskiego, Lublin 2002.

${ }^{23}$ A. Nowak, ZSRR jako przedmiot badań historycznych, „Dzieje Najnowsze”, 1994, nr 1, s. 103-111.

${ }^{24}$ I. Deutscher, Trotsky 1921-1929, New York 1959; B. Fields, Trotskyism and Maoizm, Cambridge 1967; R. Wistrich, Revolutionary Jews from Marx to Trotsky, London 1976; B. Knei-Paz, The Social and Political Thought of Leon Trotsky, Oxford 1978; J. Molyneux, Leon Trotsky's Theory of Revolution, New York 1981; T. Cliff, Trotsky, London 1989-1993; A. Callinicos, Trotskyism, Minneapolis 1990.

${ }^{25}$ M.in. L. Haimson, The Problem of Social Stability in Urban Russia 1905-1917, „Slavic Review", 1964, nr 4; E. Carr, The Soviet Impact on the Western World, New York 1947; idem, The Bolshevik Revolution, New York 1950-1953; idem, Socialism in one country 1924-1926, New York 1958-1959; idem, The Interregnum 1923-1924, Harmondsworth 1969; idem, Foundations of Planned Economy 1926-1929, London 1971; idem, The Russian Revolution from Lenin to Stalin (1917-1929), London 1979; idem, The Twilight of Comintern 1930-1935, London 1982; R. Tucker, The Soviet Political Mind. Stalinism and Post-Stalin Change, New York 1973; S. Cohen, Bolshevism and Stalinism, [w:] Stalinism: Essays in Historical Interpretation, red. R. Tucker, New York 1977; R. Tucker, The Marxian Revolutionary Idea, New York 1969; idem, Philosophy and Myth in Karl Marx, Cambridge 1971; idem, Stalin as a Revolutionary, New York 1973; The Great Purge Trial, red. R. Tucker, S. Cohen, New York 1965; S. Cohen, Common sense in US - Soviet relations, Washington 1978; idem, Bukharin and the Bolshevik Revolution. A political biography, 1888-1938, Oxford 1980; The Soviet Union since Stalin, red. S. Cohen, A. Rabinovitch, Bloomington-London 1980; An End to Silence. Uncensored Opinion in the Soviet Union, red. S. Cohen, New York-London 1982; S. Cohen, Rethinking the Soviet Experience, Oxford 1985; idem, Sovieticus: American Perceptions and Soviet Realities, New York-London 1986; idem, Failed crusade: America and the tragedy of post - Communist Russia, New York 2000; idem, The victims return: survivors of the Gulag after Stalin, Exeter 2010; M. Lewin, Lenin's Last Struggle, New York 1968; idem, The Making of the Stalinist System, New York 1985; idem, The Gorbachev phenomenon: a historical interpretation, Berkeley 1988; idem, Stalinism and the Seeds of Soviet Reforms, Armonk 1991; idem, Russia - USRR - Russia: the drive and drift of a superstate, New York 1995; idem, The Soviet century, New York 2005; Cultural Revolution in Russia 1928-1931, red. S. Fitzpatrick, Bloomington 1978; S. Fitzpatrick, Educations and Social Mobility in the Soviet Union 1921-1934, Cambridge 1979; eadem, The Russian Revolution, New York 1982; Russia in the Era of NEP, red. S. Fitzpatrick, A. Rabinowitch, R. Stites, Bloomington 1991; S. Fitzpatrick, The Cultural Front. Power and Culture in Revolutionary Russia, Ithaca 1992; eadem, Stalin's Peasants. Resistance and Survival in the Russian Village after Collectivization, New York 1994; eadem, Everyday Stalinism, New York 1999; Stalinism: New Directions, red. S. Fitzpatrick, London 2000; A. Rabinowitch, Prelude to Revolution, New York 1968; idem, The Bolsheviks come to Power, New York 1976; R. Suny, Toward a Social History of the October Revolution, „American Historical Review”, 1983, nr 2. Zob. też I. Deutscher, E. Carr as Historian of Soviet Russia, „Soviet Studia”, 1950; E. Acton, Rethinking the Russian Revolution, London 1990; J. Halsam, The Vices of Integrity. E.H. Carr 1892-1982, 
W tej interpretacji twierdzono, że Lenin dążył do tworzenia racjonalnego państwa komunistycznego, unikającego stosowania terroru na wielką skalę. Dowodzić tego miała m.in. polityka NEP oraz doktryna ekonomiczna N. Bucharina. Dopiero Stalin miał zniszczyć jakikolwiek pluralizm polityczny i rozbudować maksymalnie przerażający aparat terroru. W takim kontekście rządy Chruszczowa czy Gorbaczowa były postrzegane w optyce rewizjonistów jako próby nawiązywania do leninowskich idei „demokracji socjalistycznych”.

Z nurtem rewizjonistycznym polemizowali gwałtownie historycy opowiadający się za interpretowaniem ,rewolucji” 1917 r. wyłącznie w kategorii bolszewickiego zamachu stanu, dzięki któremu mniejszość narzuciła siłowo całemu społeczeństwu dyktatorskie rządy komunistyczne (A. Ulam, R. Conquest, B. Wolfe, L. Schapiro, A. Besancon, L. Łabędź, M. Malia, R. Pipes, M. Heller, B. Lewickyj) ${ }^{26}$. Lenin miał połączyć wybrane wątki filozofii marksistowskiej z tradycjami wschodniego i carskiego despotyzmu. $Z$ tego względu wielu badaczy (np. J. Kucharzewski, R. Pipes, A. Besancon) akcentowało swoistą ciągłość pomiędzy imperium carskim a ZSRR, szczególnie w zakresie stosowanego terroru i ekspansjonistycznej polityki zagranicznej. W ocenie m.in. R. Pipesa Hitler, tworząc system nazistowski w III Rzeszy, korzystał z wielu rozwiązań prawno-ustrojowych stosowanych w dyktatorskim reżimie Stalina. A. Besancon uznawał nawet nazizm i stalinizm za „systemu bliźniacze”.

Zwolennicy szukania analogii między III Rzeszą i ZSRR Stalina rozwijali w latach czterdziestych i pięćdziesiątych teorię totalitaryzmu, akcentującą rolę dyktatorskiej jednostki stojącej poza prawem, masowej partii poddanej jednej ,rewolucyjnej” ideologii, systemu rozbudowanego terroru policyjnego i kontroli nad wolnością indywidualną poszczególnych jednostek ${ }^{27}$. Problematykę totalitaryzmu sowieckiego i nazistowskiego w aspekcie filozoficznym rozwijała $\mathrm{H}$. Arendt, natomiast politologiczną definicję totalitaryzmu stworzył Z. Brzeziński i C. Friedrich ${ }^{28}$. Literackie wizje przerażającego systemu tota-

London-New York 1999; Writing the Stalin era. S. Fitzpatrick and Soviet Historiography, New York 2011; E. Acton, Rosja. Dziedzictwo caratu i władzy radzieckiej, Warszawa 2013.

${ }^{26}$ R. Pipes, Żyłem. Wspomnienia niezależnego, Warszawa 2004; idem, 1917 i rewizjoniści, [w:] idem, Rosja, komunizm i świat, red. A. Nowak, Kraków 2002; R. Conquest, The Great Terror, London 1968; idem, Stalin, Warszawa 2000; L. Schapiro, The Russian Revolutions of 1917, New York 1984; B. Lewickij, Terror i rewolucja, Paryż 1965; idem, The Stalinist Terror in the Thirties, Stanford 1974; M. Malia, Lekcja rewolucji rosyjskiej, Kraków 1986; idem, Russia under Western Eyes, Harvard-Cambridge 1999; idem, Sowiecka tragedia: historia komunistycznego imperium rosyjskiego 1917-1991, Warszawa 1998; R. Pipes, Rosja carów, Warszawa 1990; idem, Rewolucja rosyjska, Warszawa 1994; idem, Communism. The Vanished Specter, London-New York 1994; idem, Własność a wolność, Warszawa 2000; idem, Communism. A History, New York 2003; idem, Rosja bolszewików, Warszawa 2005.

${ }^{27}$ K. Pomian, Totalitaryzm, A. Gleason, $W$ poszukiwaniu ukrytych korzeni totalitaryzmu, P. Hassner, Totalitaryzm - ewolucja systemu i jego percepcji, „Przegląd Polityczny”, 2006, nr 79-80.

${ }^{28}$ M.in. H. Arendt, Korzenie totalitaryzmu, Warszawa 2008; M. Canovan, The Political Thought of Hannah Arendt, New York 1974; S. Whitfield, Into the Dark: H. Arendt and Totali- 
litarnego rozwijali m.in. G. Orwell, A. Koestler, A. Camus i G. Herling-Grudziński. W aspekcie ekonomicznym do czołowych krytyków totalitaryzmu i systemów gospodarki etatystycznej należał F.A. von Hayek i L. Mises ${ }^{29}$.

Za użytecznością teorii totalitaryzmu opowiadało się wielu czołowych przedstawicieli filozofii i sowietologii zachodniej, m.in. A. Ulam, M. Fainsod, R. Conquest, B. Wolfe, L. Schapiro, A. Besancon, L. Łabędź, M. Malia, R. Pipes, M. Heller, B. Lewickyj, R. Aron ${ }^{30}$. Na skutek destalinizacji po 1953 r. pa-

tarianism, Philadelphia 1980; E. Young-Bruehl, Hannah Arendt, Paris 1986; P. Hansen, H. Arendt: Politics, History and Citizenship, Stanford 1993; R. Boesche, Theories of Tyranny from Plato to Arendt, University Park 1996; W. Heller, Hannah Arendt. Źródta pluralizmu politycznego, Poznań 2000; Totalitarianism and Liberty: Hannah Arendt in the 21st century, red. G. Beiser, K. Stokłosa, A. Wisley, Kraków 2008; C. Isaac, Arendt, Camus and Modern Rebellion, New Haven 1992; M. Moskalewicz, Totalitaryzm, narracja, tożsamość. Filozofia historii Hannah Arendt, Toruń 2013; Totalitarianism, red. C. Friedrich, Cambridge 1954; C. Friedrich, Z. Brzeziński, Totalitarian Dictatorship and Autocracy, Cambridge 1955; P. Vaughan, Zbigniew Brzeziński, Warszawa 2010; A. Lubowski, Zbig - czlowiek, który podminowat Kreml, Warszawa 2011.

${ }^{29}$ J. Lewandowski, Liberalizm a współczesność, Wrocław 2013; W. Baumgarth, The political philosophy of F.A. von Hayek, Cambridge 1976; C. Hoy, A philosophy of indyvidual freedom: the political thought of F.A. von Hayek, Westport 1984; F.A. von Hayek as a political economist, London-New York 2002; B. Caldwell, Hayek's challenge: an intelllectual biography of F.A. Hayek, Chicago 2004; E. Miller, Hayek's The Constitution of liberty: an account of its argument, London 2010; E. i M. Streissler, F.A. von Hayek, Warszawa 2004; J. Godłów-Legiedź, Doktryna społeczno - ekonomiczna F. von Hayek'a, Warszawa 1992; N. Wapshott, Keynes kontra Hayek: spór, który zdefiniowat wspótczesna ekonomię, Warszawa 2013.

${ }^{30}$ M.in. M. Fainsod, How Russia is Ruled, Cambridge 1953; idem, Smoleńsk under Soviet Rule, Cambridge 1958; B. Moore, Soviet Politics - The Dilemma of Power, Cambridge 1950; idem, Terror and Progress: USSR, Cambridge 1954; B. Wolfe, The Three Who Made a Revolution, Boston 1955; idem, Six keys to the Soviet system, Boston 1956; idem, Marxism, one hundred years in the life of a doctrine, New York 1965; idem, An ideology in Power: reflections on the Russian revolution, New York 1969; idem, Revolution and reality: essays on the origin and fate of the Soviet system, Chanel Hill 1981; Breaking with communism: the intelectuall odyssey of Bertram D. Wolfe, Stanford 1990; R. Conquest, Russia after Khrushchov, New York-London 1965; idem, Where Marx went wrong?, London 1970; idem, Power and Policy in the USRR, San Francisco 1970; idem, Lenin, New York 1972; idem, Kolyma: the Arctic Death Camps, New York 1978; idem, Harvest of Sorrow: Soviet Collectivisation and the Terror Famine, New York 1986; A. Besancon, Les origins intellectuelles du leninisme, Paris 1977; idem, The Soviet syndrome, New York 1978; idem, The Rise of the Gulag, New York 1981; idem, Solżenicyn i Zachód: sowiecka teraźniejszość i rosyjska przeszłość, Warszawa 1981; idem, Anatomia widma: ekonomia polityczna realnego socjalizmu, Warszawa 1984; idem, Nacjonalizm i bolszewizm w ZSRR, Warszawa 1988; idem, Przekleństwo wieku: o komunizmie, narodowym socjalizmie i jedyności Zagłady, Warszawa 2000; L. Schapiro, Totalitarianism, London 1972; A. Ulam, Titoism and the Cominform, Cambridge 1952; idem, The New Face of Soviet Totalitarianism, Cambridge 1963; idem, The Bolsheviks. The Intelektual and Political History of the Triumph of Communism in Russia, New York 1965; idem, The Bolsheviks, New York 1968; idem, International negotiation. Communist doctrine and Soviet diplomacy, Washington 1970; idem, The rivals: America and Russia since World War II, New York 1971; idem, Stalin. The Man and His Era, Boston 1973; idem, Expansion and Coexistence. The History of Soviet Foreign Policy 1917-1973, New York 1974; idem, Ideologies and Illusions. Revolutionary Thought from Herzen to Solzhenitsyn, Harvard 1976; idem, A History of Soviet Russia, New York 1976; idem, Russia's Failed Revolutions: From the Decembrists to the Dissidents, New York 1981; idem, Dangerous Relation: the Soviet Union in World Politics 1970-1982, New York 1983; idem, The 
radygmat totalitarny był jednak coraz częściej krytykowany, albowiem ZSRR był już postrzegany jako oligarchia elity partyjnej, a nie dyktatura okrutnej jednostki. Wskazywano na stopniowo malejącą rolę terroru policyjnego. Sami zwolennicy modelu totalitarnego (np. H. Arendt, Z. Brzeziński) zakładali pewne jego modyfikacje, wynikające $z$ ewolucyjnych zmian polityczno-społecznych w krajach bloku wschodniego ${ }^{31}$. Po 1956 r., w związku z postępującym konfliktem ZSRR z Chinami oraz z rozwojem doktryny komunizmu narodowego w krajach Europy Wschodniej, w sowietologii rozwijał się dynamicznie nurt policentryzmu, zakładający coraz większe zróżnicowanie w światowym obozie komunistycznym (Z. Brzeziński, R. Aron, L. Łabędź) ${ }^{32}$. Z. Brzeziński apelował wobec tego do kierownictwa USA o zmianę polityki tego państwa poprzez wpływanie na rozbijanie jedności politycznej wśród krajów bloku wschodniego.

Część sowietologów odrzucała całkowicie teorię totalitaryzmu, twierdząc, że ZSRR przechodzi procesy rzeczywistej modernizacji społecznej, mogące prowadzić do „ograniczonego pluralizmu politycznego” (A. Inkeles, M. Lewin, R. Tucker, A. Meyer, J. Hough) ${ }^{33}$. Doktryna konwergencji zakładała stopniowe zbliżanie się do siebie społeczno-ekonomicznych modeli kapitalizmu i komunizmu. Przedstawiciele tego nurtu sowietologii popierali wszelkie tendencje reformatorskie w obrębie sowieckiej elity partyjnej, wierząc w jej rzeczywiste chęci modernizacyjne. Apelowano też o łagodzenie polityki międzynarodowej świata zachodniego wobec ZSRR.

Z tym stanowiskiem dyskutowali otwarcie zwolennicy ,szkoły totalitarnej” (R. Pipes, Z. Brzeziński, A. Ulam, M. Malia, A. Besancon), gdyż w ich

Communists. The Story of Power and Lost Illusions, New York 1992; idem, Understanding the Cold War: a historian's personal reflections, London 2002 oraz The Soviet empire reconsidered: essays in honor of Adam B. Ulam, Boulder 1994.

31 Zob. m.in. Z. Brzeziński, Totalitarianism and Rationality, „American Political Science Review”, 1956, nr 9; idem, The Soviet Political System: Transformation or Degeneration, „Problems of Communism”, 1966, nr 1; B. Meissner, Totalitarian Rule and Social Change, „Problems of Communism”, 1966, nr 6; C. Freidrich, Totalitarianism: Recent Trends, „Problems of Communism”, 1968, nr 3; Z. Brzeziński, Reflections on the Soviet System, „Problems of Communism”, 1968, nr 3.

32 Np. M. Croan, The Dialectic of Polycentrism, ,Survey”, 1963, nr 48; Communism in Europe: Continuity, and Change and the Sino-Soviet Dispute, red. W. Griffith, Cambridge 1964-1966; W. Griffith, World Communism Divided, „Foregin Association”, 1964, nr 116; R. Aron, On Polycentrism, „Survey”, 1966, nr 58; The Communist States at the Crossroads, New York 1965; A. Low, The Sino-Soviet Dispute, Rutheford 1976; R. Lowenthall, World Communism, New York 1966; B. Łomiński, Teoria policentryzmu, Katowice 1991.

${ }^{33}$ A. Meyer, Theories of Convergence, [w:] Change in the Communist System, red. C. Johnson, Stanford 1970; P. Hassner, Totalitaryzm, ewolucja systemu, s. 150; H.G. Skilling, Interest Groups and Communist Politics, „World Politics”, 1966, nr 3; A. Meyer, The Soviet Political System, New York 1965; idem, USRR Incorporated, „Slavic Review”, 1961, nr 3; R. Tucker, The Question of Totalitarianism, „Slavic Review”, 1961, nr 3; J. Hough, The Soviet Union and Social Science Theory, Cambridge 1977; idem, Pluralism, Corporatism and the Soviet Union, [w:] Pluralism in the Soviet Union, London 1983. 
opinii ZSRR nie był skłonny do rzeczywistych gruntownych reform liberalizacyjnych czy demokratyzacyjnych. Popierali ich od połowy lat siedemdziesiątych wschodnioeuropejscy i rosyjscy emigranci oraz opozycyjni dysydenci, podkreślający ciągle totalitarny charakter sowieckiego państwa (A. Sołżenicyn, A. Sinawskij, A. Sacharow, W. Bukowski, M. Voslensky, A. Zinowiew itd.) ${ }^{34}$. Na tym stanowisku stała również zdecydowana większość emigrantów polskich, w tym przede wszystkim związanych ze środowiskiem paryskiej „Kultury” J. Giedroycia.

Swoisty renesans teorii totalitaryzmu przyniosły lata osiemdziesiąte XX wieku i zdecydowana antykomunistyczna polityka zagraniczna R. Reagana kreowana przez środowiska neokonserwatywne ${ }^{35}$. Mimo tego część sowietologów-rewizjonistów (np. S. Cohen, M. Lewin) wierzyło w reformatorski potencjał Gorbaczowa, który miał przywrócić rzekomo pozytywne leninowskie standardy w zarządzaniu społeczeństwem komunistycznym.

Ostateczny upadek bloku wschodniego i samego ZSRR oznaczał kompromitację sowietologicznych teorii modernizacyjnych. A. Walicki zauważył słusznie, że również zwolennicy szkoły totalitarnej nie byli w stanie przewidzieć tak szybkiego upadku ZSRR i rozpadu całego systemu krajów zależnych ${ }^{36}$.

${ }^{34} \mathrm{Na}$ temat wieloaspektowej antytotalitarnej działalności dysydentów, niezależnych pisarzy i obrońców praw człowieka w ZSRR i innych krajach bloku wschodniego zob. m.in. D. Reinhartz, Milovan Djilas. A Revolutionary as a Writer, New York 1981; M. Lustig, Trotsky and Djilas: Critics of Communist Bureaucracy, New York 1989; Samizdat Voices of the Soviet Opposition, red. G. Saunders, New York 1974; Dissent in the USRR. Politics, Ideology and People, red. R. Tokes, Baltimore 1975; F. Feldbrugge, Samizdat and Political Dissent in the Soviet Union, Leyden 1975; The Political, Social and Religious Thought of Russian ,, Samizdat” - An Anthology, Belmont 1977; M. Shatz, Soviet Dissent in Historical Persepctive, Cambridge 1980; H. Skilling, Charter 77 and Human Rights in Czechoslovakia, London 1981; J. Woll, V. Treml, Soviet Dissident Literature, Boston 1983; J. Rubenstein, Soviet Dissidents, Boston 1985; J. Bilocerkowicz, Soviet Ukrainian Dissent. A Study of Political Alienation, Boulder-London 1988; G. Skilling, Samizdat and an Independent Society in Central and Eastern Europe, London 1990; The Road to Post-Communism. Independent Political Movements in the Soviet Union 1985-1991, red. G. Hosking, J. Aves, P. Rucam, London 1992; B. Falk, The Dilemmas of Dissidence in East-Central Europe. Citizen Intellectuals and Philosopher Kings, Budapest 2003; Ruch demokratyczny w ZSRR, Warszawa 1981; P. Litwinow, Narodziny ruchu obrony praw człowieka w ZSRR, Warszawa 1985; Literatura emigracyjna Rosjan, Ukraińców i Białorusinów, Lublin 2001; M. Iwanow, Sowiecki ruch dysydencki a Polska, [w:] Czas przełomu. „Solidarność” 1980-1981, Gdańsk 2010; A. Sacharow, Wspomnienia, Warszawa 1993; The case of Vladimir Bukovsky, „Survey”, 1972, nr 2; M. Scamwell, Solzhenitsyn: A Biography, London 1985; L. Suchanek, Aleksander Solżenicyn. Pisarz i publicysta, Kraków 1994; J. Litwinow, Solżenicyn i Polska, Poznań 1997; R. Lourie, Sakharov. A Biography, Hannover 2002; Stownik dysydentów. Cz. II, Warszawa 2007.

35 M.in. P. Steinfels, The Neoconservaties, New York 1979; Neokonserwatyzm, red. I. Stelzer, Warszawa 2007; N. Abrams, Norman Podhoretz and „Commentary” magazine: the rise and fall of the neocons, New York 2010; ,Commentary” in American life, red. M. Friedman, Philadelphia 2005; T. Jeffers, Norman Podhoretz: a biography, Cambridge 2010; I. Kristol, Neoconservatism: the autobiography of an idea, Chicago 1999; idem, The neoconservative persuasion: selected essays 1942-2009, New York 2011.

36 A. Walicki, Marksizm i skok do królestwa wolności, Warszawa 1996. 
Spór dotyczący genezy i oceny totalitaryzmu sowieckiego i nazistowskiego jest prowadzony do dzisiaj ${ }^{37}$. Po upadku komunizmu tradycyjna lewicowo-marksistowska krytyka nazizmu i faszyzmu straciła praktycznie na znaczeniu na rzecz ujmowania tych fenomenów ustrojowo-ideologicznych w kategoriach paradygmatu totalitarnego ${ }^{38}$. W kategorii totalitaryzmu ujmowali III Rzeszę m.in. K. Bracher, H. Buchheim, M. Broszat, G. Mann ${ }^{39}$.

Po 1989 r. kontynuowano na Zachodzie prace badawcze dotyczące faszyzmu i nazizmu, wiele istotnych monografii zostało przy tym przetłumaczonych na język polski, wpływając na rozwój polskich badań w tym za$\mathrm{kresie}^{40}$. Były one prowadzone przede wszystkim w ośrodku warszawskim

${ }^{37}$ M. Malia, Rosja: nowe interpretacje - stare złudzenia , „Przegląd Polityczny”, 2001, nr 48.

38 Z. Krasnodębski, Intelektualne źródła totalitaryzmu, s. 91.

39 Ibidem, s. 94.

40 Zob. m.in. R. Gellately, The Gestapo and German Society, Oxford 1990; K. Hilderbrand, Das Dritte Reich, Munchen 1991; M. Burleigh, W. Wippermann, The Racial State: Germany 1933-1945, Cambridge-New York 1991; O. Bartor, Hitler's Army: Soldiers, Nazis and War in the Third Reich, New York 1991; C. Fest, Hitler. Eine Biographie, Berlin 1992; I. Kershaw, The Nazi Dictatorship, London 1993; T. Mason, Social Policy in the Third Reich, Providence 1993; R. Griffin, The Nature of Fascism, London 1993; Nationalsozialismus und Modernisierung, red. M. Prinz, R. Zitelman, Darmstadt 1994; Fascism, red. R. Griffin, Oxford 1995; H. Friedlander, The Origins of Nazi Genocide, Chapel Hill 1995; G. Aly, ,Final solution”: Nazi Population Policy and the Murder of the European Jews, London-New York 1999; E. Johnson, Nazi Terror: The Gestapo, Jews and Ordinary Germans, New York 1999; I. Kershaw, The Nazi Dictatorship: Problems and Perspectives of Interpretation, London 2000; G. Lewy, The Catolic Church and Nazi Germany, Warszawa 2000; G. Gentile, Fascismo. Storia e interpretazione, Roma 2002; C. Fisher, The Rise of the Nazis, Manchester-New York 2002; D. Williamson, The Third Reich, London 2003; D. Cesarani, Eichmann, London 2003; Fascism: critical concepts in political science, vol. 1-4, London-New York 2004; C. Browning, J. Matthaus, The Origins of the Final Solution: The Evolution of Nazi Jewish Policy, Lincoln-Jerusalem 2004; S. Aronson, Hitler, the allies and the Jews, Cambridge 2006; R. Evans, The Third Reich in power: 1933-1939, London 2006; W. Schivelbusch, Three New Deals: Reflections on Roosevelt's America, Mussolini's Italy and Hitler's Germany 1933-1939, New York 2006; A. Moses, German Intellectuals and the Nazi Past, Cambridge 2007; S. Friedlander, Nazi Germany and the Jews, New York 2007; R. Griffin, Modernism and Fascism: The Sense of a Beginning under Mussolini and Hitler, New York 2007; K. Heiden, A history of national socialism, New York 2010; S. Lee, Hitler and Nazi Germany, New York 2010; E. Jackel, Panowanie Hitlera. Spetnienie światopogladu, Wrocław 1989; Historikerstreit. Spór o miejsce III Rzeszy w historii Niemiec, Londyn 1990; V. Farias, M. Heidegger i narodowy socjalizm, Warszawa 1997; W. Laqueur, Faszyzm: wczoraj, dziś, jutro, Warszawa 1998; R. Eatwell, Faszyzm. Historia, Poznań 1999; D. Goldhagen, Gorliwi kaci Hitlera. Zwyczajni Niemcy i Holocaust, Poznań 1999; R. Rosenbaum, Wyjaśnianie Hitlera - w poszukiwaniu źródet zła, Warszawa 2001; M. Burleigh, Trzecia Rzesza. Nowa Historia, Warszawa 2002; I. Kershaw, Hitler 1889-1939, Poznań 2001-2002; M. Steinert, Hitler, Wrocław 2001; N. Frei, Państwo wodzowskie, Warszawa 2003; R. Paxton, Anatomia faszyzmu, Warszawa 2005; G. Aly, Państwo Hitlera, Gdańsk 2006; P. Fritzsche, Życie i śmierć w Trzeciej Rzeszy, Kraków 2010; E. Traverso, Europejskie korzenie przemocy nazistowskiej, Warszawa 2011; E. Gentile, Poczatki ideologii faszystowskiej (1918-1925), Warszawa 2011; D. Bergen, Wojna i ludobójstwo krótka historia Holocaustu, Poznań 2011; A. Nagorski, Hitlerland: jak naziści zdobywali władzę, Warszawa 2012; M. Kitchen, Trzecia Rzesza: charyzma i wspólnota, Warszawa 2012. Zob. również M. Zmierczak, Spory historyków i politologów o ustrój Trzeciej Rzeszy, [w:] Studia z historii ustroju i prawa, red. H. Olszewski, Poznań 2002. 
(J. Borejsza, F. Ryszka), wrocławskim (K. Jonca, M. Maciejewski, M. Marszał, L. Górnicki), poznańskim (H. Olszewski, M. Zmierczak) i krakowskim (W. Kozub-Ciembroniewicz) ${ }^{41}$. Na łamach wrocławskich „Studiów nad Faszyzmem i Zbrodniami Hitlerowskimi” prezentowano regularnie wyniki badań prowadzonych przez uczonych zachodnich i polskich ${ }^{42}$. Podejmowane są również badania w zakresie ustrojów autorytarnych (w Hiszpanii, Portugalii, Europie Środkowo-Wschodniej przed 1939 r. oraz w Ameryce Południowej). M. Maciejewski i M. Marszał opublikowali ponadto antologie polskiej przedwojennej literatury naukowej poświęconej ocenie faszyzmu i hitleryzmu ${ }^{43}$.

$\mathrm{W}$ badaniach dotyczących marksizmu-leninizmu, komunizmu, bolszewizmu i sowietyzmu uczestniczą od 1989 r. bardzo aktywnie polscy specjaliści w zakresie historii Rosji, ZSRR i państw komunistycznych, politolodzy, prawnicy, socjolodzy, literaturoznawcy i filozofowie ${ }^{44}$.

41 J. Borejsza, Szkoły nienawiści. Historia faszyzmów europejskich 1919-1945, Wrocław 2000; L. Górnicki, Prawo Trzeciej Rzeszy w nauce i publicystyce prawniczej Polski międzywojennej (1933-1939), Bielsko-Biała 1993; M. Maciejewski, Doktryna rewolucyjnego konserwatyzmu wobec narodowego socjalizmu 1921-1945, Wrocław 1991; idem, Niemieckie elity a hitleryzm, Wrocław 1994; idem, Od piwiarnianego klubu do organizacji wywrotowej: nazizm w latach 1919-1924, Toruń 2006; M. Marszał, Włoski faszyzm w polskiej myśli politycznej i prawnej 1922-1939, Wrocław 2007; idem, Włoski faszyzm i niemiecki narodowy socjalizm w pogladach ideologów Narodowej Demokracji 1926-1939, Wrocław 2001; W. Kozub-Ciembroniewicz, Doktryny włoskiego faszyzmu $i$ antyfaszyzmu w latach 1922-1939, Kraków 1992; idem, Doktryna i system władzy Włoch faszystowskich na tle porównawczym, Kraków 2010. Zob. też prace innych autorów, np. O. Hinc, Cywilizacyjna interpretacja faszyzmu, Toruń 2001; Nazizm, Trzecia Rzesza a procesy modernizacji, red. H. Orłowski, Poznań 2003; J. Wieliczka-Szarek, III Rzesza-narodziny i zmierzch szaleństwa, Kraków 2006; A. Kmak-Pamirska, Religia w czasach Trzeciej Rzeszy, Toruń 2010; M. Podstawski, Faszyzm jako uobecnienie mitu rewolucji, Torun 2012.

${ }^{42}$ M. Zmierczak, Totalitaryzm - Faszyzm - Hitleryzm. Z historii sporów o genezę i istotę nazizmu w historiografii RFN, SFZH, 1991; H. Olszewski, Świat nauki wobec wyzwań narodowego socjalizmu. Przegląd badań, SFZH, 1993; H. Orłowski, Pułapki paradygmatu modernizacji. Wokót najnowszych dyskusji na nazizmem i Trzecia Rzesza, SFZH, 1996; M. Maciejewski, Historiografia narodowego socjalizmu w RFN. Glówne watki badawcze, SFZH, 1997; idem, Hiszpański faszyzm i frankizm w polskiej literaturze politycznej i naukowej (1936-1997), SFZH, 1998; M. Zmierczak, Pozytywizm prawniczy a prawnicy i prawo $w$ Trzeciej Rzeszy - powojenna dyskusja niemieckich historyków i teoretyków prawa o przyczynach upadku prawa w czasach nazizmu, SFZH, 2001; eadem, Spory o Adolfa Hitlera w najnowszej literaturze, SFZH, 2003.

${ }^{43}$ Amica Italia. Polscy prawnicy wobec wtoskiego faszyzmu 1922-1939, opr. M. Marszał, Kraków 2004; Pod znakiem swastyki. Polscy prawnicy wobec Trzeciej Rzeszy 1933-1939, opr. M. Maciejewski, M. Marszał, Kraków 2005.

${ }^{4}$ A. Nowak, ZSRR jako przedmiot badań historycznych, „Dzieje Najnowsze”, 1994, nr 1, s. 103-111; Stalinizm, red. J. Kurczewski, Warszawa 1989; W. Dziak, Stalin, stalinizm, stalinowcy, Warszawa 1990; J. Muszyński, Mechanizm władzy ZSRR: organy bezpieczeństwa, Warszawa 1991; idem, Powstanie i upadek imperium radzieckiego, Warszawa 1991; K. Karski, Proces rozpadu Zwiazku Radzieckiego, Warszawa 1992; Totalitarianism and the challenge of democracy, red. A. Jabłoński, W. Piasecki, Wrocław 1992; R. Backer, Totalitaryzm: geneza, istota, upadek, Toruń 1992; J. Smaga, Narodziny i upadek imperium. ZSRR 1917-1991, Kraków 1992; M. Smoleń, Stracone dekady: historia ZSRR 1917-1991, Warszawa 1994; Polityka zagraniczna Rosji i ZSRR, red. W. Materski, Łódź 1994; W. Marciniak, Rozgrabione imperium: upadek Związku Sowieckiego 
Istotne badania nad systemem komunistycznym w Rosji i w Polsce W aspekcie głównie ustrojowo-prawnym prowadzą od kilkunastu lat z dużym powodzeniem historycy państwa i prawa oraz historycy doktryn politycznych i prawnych (m.in. H. Izdebski, A. Lityński, A. Bosiacki, K. Kuźmicz ${ }^{45}$. Historycy prawa akcentowali liczne różnice pomiędzy prawem państwa komunistycznego a zachodnioeuropejskimi tradycjami prawnymi (odrzucenie konstytucyjnych gwarancji ochrony praw jednostki, postrzeganie prawa jako instrumentu sprawowania władzy przez warstwę rządzącą, ograniczanie zna-

i powstanie Federacji Rosyjskiej, Warszawa 1994; M. Bankowicz, Kulisy totalitaryzmu, Kraków 1995; F. Bernaś, J. Wilczur, Piekielny krag. Z dziejów Czeka, GPU, NKWD, Warszawa 1995; Skryte oblicze systemu komunistycznego. U źródet zła, red. R. Backer, P. Hubner, Warszawa 1997; Historia literatury rosyjskiej XX wieku, red. A. Drawicz, Warszawa 1997; R. Dzwonkowski, Kościót katolicki w ZSRR 1917-1939. Zarys historii, Lublin 1997; Nazizm i sowietyzm w świadomości historycznej, Warszawa 1997; A. Nowak, Polacy, Rosjanie i biesy. Studia i szkice historyczne z XIX i XX w., Kraków 1998; A. Kastory, Ztowrogie sąsiedztwo. Rosyjska polityka wobec europejskich państw ościennych w latach 1939-1949, Kraków 1998; R. Stobiecki, Bolszewizm a historia. Próba rekonstrukcji bolszewickiej filozofii dziejów, Łódź 1998; B. Olszewska-Dyoniziak, Antropologia totalitaryzmu europejskiego XX wieku, Wrocław 1999; H. Świda-Ziemba, Człowiek wewnętrznie zniewolony, Warszawa 1999; J. Holzer, Komunizm w Europie. Dzieje ruchu i systemu władzy, Warszawa 2000; Totalitaryzm - przeszłość czy realne zagrożenie?, red. R. Fiedler, S. Wojciechowski, Poznań 2001; Komunizm: ideologia, system, ludzie, red. T. Szarota, Warszawa 2001; E. Możejko, Realizm socjalistyczny. Teoria. Rozwój. Upadek, Kraków 2001; J. Smaga, Rosja w 20 stuleciu, Kraków 2001; P. Wieczorkiewicz, Łańcuch śmierci: czystka w Armii Czerwonej 1937-1939, Warszawa 2001; R. Skarżyński, Od liberalizmu do totalitaryzmu: z dziejów myśli politycznej XX w., Warszawa 2002; P. Kołakowski, NKWD i GRU na ziemiach polskich 1939-1945, Warszawa 2002; M. Kula, Religiopodobny komunizm, Kraków 2003; Totalitaryzm. Wybrane problemy teorii i praktyki, red. T. Wallas, Poznań 2003; W. Roszkowski, Pótwiecze. Historia polityczna świata po 1945 roku, Warszawa 2003; K. Tyszka, Nacjonalizm w komunizmie: ideologia narodowa w Zwiazku Radzieckim i Polsce Ludowej, Warszawa 2004; Rosja - XX wiek. Od utopii komunistycznej do rzeczywistości globalistycznej, Kraków 2004; L. Bazylow, P. Wieczorkiewicz, Historia Rosji, Wrocław 2005; Totalitarian and Authoritarian Regimes in Europe, red. J. Borejsza, K. Ziemer, New York 2006; Rosja i Europa Wschodnia: ,imperiologia stosowana”, red. A. Nowak, Kraków 2006; M. Kula, Komunizm i po komunizmie, Warszawa 2006; H. Głębocki, Kresy Imperium. Szkice i materiały do dziejów polityki Rosji wobec jej peryferii (XVIII-XXI w.), Kraków 2006; M. Bankowicz, W. Kozub-Ciembroniewicz, Dyktatury i tyranie. Szkice o niedemokratycznej władzy, Kraków 2007; Fenomen rosyjskiego komunizmu: geneza, konteksty, konsekwencje, red. B. Brzeziński, Poznań 2010; J. Holzer, Europa zimnej wojny, Kraków 2012; J. Tokarski, Historie przyszłości: wizje bolszewizmu w Rosji 1917-1921, Warszawa 2012; E. Duraczyński, Stalin. Twórca i dyktator supermocarstwa, Pułtusk-Warszawa 2012.

45 W. Wołodkiewicz, Reżimy autorytarne a prawo rzymskie, CPH, 1993, z. 1-2; W. KozubCiembroniewicz, Władza totalitarna a model państwa prawnego, SFZH, 2008; M. Filar, W stużbie utopii. 73 lata radzieckiego prawa karnego, Toruń 1992; K. Kuźmicz, Jednostka a totalitaryzm. Czy filozofowie przyczynili się do narodzin systemów totalitarnych?, [w:] Człowiek przeciwko człowiekowi. Filozofia, polityka i prawo a systemy totalitarne, red. I. Grat, Białystok 2008; K. Kuźmicz, Prawo w utopii komunistycznej. Zarys problematyki, „Zeszyty Prawnicze UKSW”, 2011, nr 4; A. Stawarska-Rippel, Radziecka procedura cywilna: totalitarna czy nowoczesna, SFZH, 2011, s. 467-479; A. Bosiacki, H. Izdebski, Konstytucjonalizm rosyjski - historia i wspótczesność, Kraków 2013. 
czenia prawa prywatnego, zinstrumentalizowanie sądownictwa i prokuratury, represyjny charakter prawa karnego itd. $)^{46}$.

W nauce zachodniej i krajowej postuluje się również coraz częściej konieczność analizowania fenomenu totalitarnego w ujęciu porównawczym poprzez szukanie podobieństw i różnic pomiędzy faszyzmem, nazizmem i komunizmem ${ }^{47}$. Chodzi też o szerokie interdyscyplinarne ujęcie tej tematyki przy użyciu metodologii nauk historycznych, socjologicznych, prawnych, politologicznych i filozoficznych. System totalitarny winien być bowiem analizowany $\mathrm{w}$ aspekcie ustrojowo-normatywnym, politologiczno-instytucjonalnym, społeczno-ekonomicznym oraz filozoficznym.

Jeszcze w 1991 r. w Filadelfii odbyła się międzynarodowa konferencja interdyscyplinarna z udziałem wielu znanych badaczy totalitaryzmu z Rosji, Niemiec, USA, Francji i Wielkiej Brytanii. Materiały konferencyjne wydano w języku angielskim w 1997 r., ale dopiero teraz zostały opublikowane w thumaczeniu na język polski ${ }^{48}$. Nie ma to jednak znaczenia, albowiem są one w dalszym ciągu w zdecydowanej większości aktualne i przydatne dla

46 M.in. A. Bosiacki, Utopia, władza, prawo. Doktryna i koncepcje prawne ,,bolszewickiej”" Rosji 1917-1921, Warszawa 1999; A. Lityński, Prawo Rosji i ZSRR 1917-1991, czyli historia wszechzwiązkowego komunistycznego prawa (bolszewików). Krótki kurs, Warszawa 2010. Zob. też opracowania tej tematyki autorów zachodnich H. Kelsen, The Communist Theory of Law, New York 1955; H. Berman, Justice in the USRR, Cambridge-London 1963; K. Stoyanovich, La philosophie du droit en URSS (1917-1953), Paris 1965; Soviet Criminal Law and procedure, the RSFSR codes, red. H. Berman, Cambridge 1966; Basic laws on the structure of the Soviet state, red. H. Berman, J. Quigley, Cambridge 1969; J. Hazard, Communists and their Law, Chicago-London 1969; Marxistische und Sozialistische Rechtsteorie, red. N. Reich, Frankfurt 1972; J. Hazard, Settling Disputes in Soviet Society. The Formative Years of Legal Institutions, New York 1978; W. Butler, Soviet Law, London 1983; E. Huskey, Russian Lawyers and the Soviet State, Princeton 1986; Revolution in Law. Contributions to the Development of Soviet Legal Theory 1917-1938, red. P. Beirne, Armonk 1990; O. Taiwo, Legal Naturalism: A Marxist Theory of Law, New York-London 1996.

47 M.in. J. Borejsza, Faszyzm, narodowy socjalizm i stalinizm z perspektywy XXI stulecia, „Studia nad Faszyzmem i Zbrodniami Hitlerowskimi” 2002, s. 35-44; E. Nolte, Der Europaische Burgerkrieg 1917-1941. Nationalsocialismus und Bolschewismus, Frankfurt 1989; I. Golomshtok, Totalitarian Art in the Soviet Union, the Third Reich, Fascist Italy and the People's Republic of China, New York 1990; G. Armanski, Maschinen des Terrors: Das Lager (KZ und GULAG) in der Moderne, Munster 1993; I. Antonow, J. Merkert, Berlin - Moskau 1900-1950, New York 1995; F. Furet, E. Nolte, Fascisme et communisme, Paris 1998; Stalinisme et nazisme, Brussels 1999; A. Todd, The European Dictators: Hitler, Stalin, Mussolini, Cambridge 2002; M. Malia, Judging Nazism and Communism, ,The National Interest”, 2002, nr 64; Fascism, Totalitarianism and Political Religion, red. R. Griffin, London-New York 2005; R. Gellately, Lenin, Stalin and Hitler. The Age of Social Catastrophe, New York 2007; M. Geyer, S. Fitzpatrick, Beyond Totalitarianism. Stalinism and Nazism Compared, Cambridge 2009; T. Snyder, Bloodlands: Europe between Hitler and Stalin, New York 2010; T. Judt, T. Snyder, Thinking the Twentieth Century, London 2012; A. Besancon, Przekleństwo wieku: o komunizmie, narodowym socjalizmie $i$ jedyności Zagłady, Warszawa 2000; R. Overy, Dyktatorzy: Hitler i Stalin, Wrocław 2009; L. Niekrasz, Dwaj jeźdźcy Apokalipsy. Stalin i Hitler - biografia porównawcze, Warszawa 2003.

48 Stalinism and Nazism: Dictatorship in Comparison, red. I. Kershaw, M. Lewin, CambridgeNew York 1997. 
projektu badań porównawczych w zakresie totalitaryzmu sowieckiego i hitlerowskiego. Celem konferencji nie było tworzenie ujęć syntetyzujących (z powodu ograniczeń metodologicznych czy archiwalnych), jej uczestnicy chcieli zaprezentować poszczególne aspekty reżimów totalitarnych, by szukać między nimi oczywistych analogii i jednocześnie wskazywać na określone różnice systemowe ${ }^{49}$.

Organizatorzy konferencji, I. Kershaw i M. Lewin, podkreślili zasadnie, że analizy totalitarnej przeszłości mają nadal znaczenie dla aktualnych sporów politycznych, prowadzonych w Rosji, Niemczech i całym świecie zachodnim. W trakcie konferencji starano się porównywać wybrane aspekty funkcjonowania państwa totalitarnego, z różnych powodów pomijając kwestie dotyczące aparatów terroru, organizacji sił zbrojnych oraz wpływu dyktatorskich reżimów na kształtowanie politycznych postaw tzw. zwykłych obywateli ${ }^{50}$.

Poszczególni badacze wielokrotnie akcentowali przydatność literatury dotyczącej nazizmu dla prowadzenia pogłębionych studiów w zakresie stalinizmu. Michael Mann wskazywał na podobieństwa i różnice w przebiegu rewolucji totalitarnej w ZSRR i III Rzeszy w ujęciu socjologicznym ${ }^{51}$. Według Manna zwolennicy teorii totalitaryzmu wskazywali trafnie na jego obligatoryjne składniki, czyli ideologię rewolucyjną, masową partię i rozbudowaną biurokrację, ale nie zauważali rosnącej sprzeczności między aktywnością dynamicznych ośrodków partyjnych a w pewnym sensie konserwatywnymi instytucjami nomenklatury, co doprowadziło ostatecznie do destrukcji rewolucyjnej dynamiki ${ }^{52}$. Przemoc reżimu wobec ,autonomicznej” biurokracji miała być dowodem jego słabości, a nie siły ${ }^{53}$. Oba reżimy odrzucały w jego ocenie politykę zawierania ,instytucjonalnych kompromisów” na rzecz brutalnej aktywności „rewolucyjnej”54. Taka taktyka miała prowadzić ostatecznie do autodestrukcji obu systemów totalitarnych. Mann podzielał tezy o analogiach $\mathrm{w}$ zakresie terroru i masowych zbrodni dokonywanych przez nazizm i stalinizm ${ }^{55}$.

Ronald Suny, analizując fenomen absolutnej władzy Stalina, nawiązywał wyraźnie do niemieckich sporów prowadzonych w kwestii oceny reżimu Hitlera przez ,intencjonalistów” i ,strukturalistów" ${ }^{56}$. W jego ocenie legitymizacja Stalina wynikała ze stosowanego terroru, ale również z określonego

49 „Stalinizm i nazizm. Porównanie dyktatur”, red. I. Kershaw, M. Lewin, Gdańsk 2015, s. 10, 15.

50 Ibidem, s. 20-21.

51 Ibidem, s. 175-201. Zob. też np. T. Abel, Why Hitler Came into Power, New York 1938; W. Allen, The Nazi Seizure of Power, Chicago 1965; I. Kershaw, The Nazi Dictatorship, London 1993; S. Cohen, Rethinking the Soviet Experience, New York 1985.

52 „Stalinizm i nazizm. Porównanie dyktatur”, s. 176-177, 179.

53 Ibidem, s. 180.

54 Ibidem, s. 185-187.

55 Ibidem, s. 195.

${ }^{56}$ Ibidem, s. 41-71. 
poparcia pewnej części społeczeństwa. Dyktator dążył do centralizacji zarządzania, ale jednocześnie paradoksalnie zostawiał pewną autonomię władzom regionalnym (podobnie jak Hitler w III Rzeszy). Charakter stalinizmu wynikał z osobistych negatywnych cech Stalina, ale był on kształtowany również przez popierającą go „nową klasę” rządzących nowych elit partyjnych. Suny uznawał nieco prowokacyjnie reżim Stalina za jednocześnie rewolucyjny i konserwatywny, dążył on bowiem do modernizacji zacofanego kraju, ale z zachowaniem wielu tradycyjnych wartości politycznych (przy legitymizowaniu systemu oparto się na marksizmie, nacjonalizmie i etatyzmie) $)^{57}$. Zdaniem Suny'ego istotą państwa sowieckiego był rozrośnięty aparat partyjnej biurokracji, który przetrwał jednoosobową dyktaturę i masowe czystki partyjne lat trzydziestych, a po 1956 r. podlegał już zespołowym rządom partyjnej oligarchii ${ }^{58}$. W badaniach nad sowiecką biurokracją (prowadził je przed 1989 r. m.in. M. Dżilas i M. Voslensky) zalecano studiowanie niemieckiej literatury naukowej dotyczącej biurokracji pruskiej i hitlerowskiej ${ }^{59}$.

Moshe Lewin wskazał w swoim referacie na narastające sprzeczności między despotyzmem Stalina a rozrastającą się biurokracją partyjną, dążącą do utrzymania określonych przywilejów i zapewnienia gwarancji bezpieczeństwa $^{60}$. W jego ocenie struktury „nowej klasy” rozwijały się paradoksalnie w okresie nasilonych masowych czystek partyjnych. Biurokracja komunistyczna przypominała rozbudowaną administrację państwa carskiego, ale jej ekspansywny rozwój wynikał dodatkowo z nacjonalizacji i podporządkowania państwu stalinowskiemu praktycznie całej gospodarki narodowej ${ }^{61}$. Biurokracja stała się ostatecznie de facto istotą ustroju komunistycznego ${ }^{62}$. Po śmierci Stalina biurokracja zlikwidowała instytucjonalne ramy dyktatury jednostki, stając się rzeczywistym podmiotem władzy w ZSRR ${ }^{63}$.

W innym wystąpieniu Lewin analizował genezę kultu Stalina, który odwoływał się w tym zakresie wyraźnie do tradycji carskich, nacjonalistycznych czy nawet quasi-religijnych ${ }^{64}$. Jego wyłącznie jednoosobowa władza miała stanowić zaprzeczenie ideologii bolszewickiej i doktryny Lenina. Zdaniem Lewina „kult jednostki” był niezbędny dla trwania reżimu stalinowskiego, ale nie był czynnikiem obligatoryjnym dla dalszego utrzymania władzy sowieckiej w ZSRR. Lewin podkreślał dużą zbieżność pomiędzy oficjalnym kultem

57 Ibidem, s. 55-56.

58 Np. R. Conquest, The Great Terror, New York 1968; J. Getty, Origins of the Great Purges, Cambridge 1985; Stalinist Terror: New Perspectives, Cambridge 1993.

59 M. Dżilas, Nowa klasa wyzyskiwaczy, Paryż 1957; M. Voslensky, Nomenklatura, Garden City 1984; ,Stalinizm i nazizm. Porównanie dyktatur”, s. 23.

60 Ibidem, s. 73-99.

61 Ibidem, s. 88.

62 Ibidem, s. 90.

63 Ibidem, s. 97.

64 Ibidem, s. 141-174. 
Stalina w ZSRR a mitem Hitlera propagowanym w okresie III Rzeszy ${ }^{65}$. Obaj dystansowali się od struktur partyjnych i administracyjnych, kreując się jako nieomylni wodzowie-dyktatorzy ${ }^{66}$. Były też jednak liczne różnice między nimi, Stalin np. ingerował w kwestie propagandy, literatury i sztuki o wiele głębiej niż Hitler ${ }^{67}$.

Bernd Bonwetsch opisał działania Stalina w okresie wojny jako wodza Armii Czerwonej, analizując jego postawę w kategoriach typowych zarówno dla niemieckich ,intencjonalistów" jak i „strukturalistów" ${ }^{68}$. Stalin był osobiście odpowiedzialny za znaczne osłabienie wojska poprzez przeprowadzenie przedwojennych czystek wśród wyższych oficerów, jednak po 1942 r. postawił na profesjonalizację $\mathrm{w}$ zakresie zarządzania operacjami militarnymi, dając większą autonomię decyzyjną poszczególnym dowódcom. Wprowadził też do armii tradycje carskie ${ }^{69}$.

Jacques Sapir postawił natomiast w swoim referacie dosyć kontrowersyjną tezę o zmianie polityki przemysłowej i zbrojeniowej Stalina w czasie wojny, co miało doprowadzić rzekomo do „demobilizacji” gospodarki państwowej i rozwoju pewnych określonych mechanizmów rynkowych ${ }^{70}$. Miało to zdaniem autora dowodzić teoretycznych możliwości dostosowania sowieckiej ekonomii do gospodarki rynkowej, czego Stalin nie uczynił w okresie powojennym wyłącznie z powodów politycznych i ideologicznych ${ }^{71}$.

Interesującej analizy ewolucji sowieckiej i rosyjskiej interpretacji dziejów II wojny światowej dokonał w swoim referacie Mark von Hagen ${ }^{72}$. W okresie powojennym dominowała oficjalna „bohaterska” wizja „Wielkiej Wojny Ojczyźnianej”, która w latach osiemdziesiątych była uzupełniania ocenami rewizjonistycznymi i nurtem odwołującym się do ,antystalinowskiej tradycji leninowskiej" "73. Autor zaapelował o międzynarodowe badania dotyczące rzeczywistego przebiegu działań wojennych na terenie ZSRR i Europy Wschodniej.

Von Hagen opisał też rosyjskie dyskusje nad fenomenem stalinizmu, przypominające niemieckie spory dotyczące historii III Rzeszy ${ }^{74}$. Również w jego ocenie do debaty nad stalinizmem przydatne są niemieckie teorie „,in-

${ }^{65}$ Ibidem, s. 142, 157-163.

${ }^{66}$ Ibidem, s. 158.

${ }^{67}$ Ibidem, s. 171.

${ }^{68}$ Ibidem, s. 28, 233-259.

${ }^{69}$ Ibidem, s. 254.

70 Ibidem, s. 261-295.

71 Ibidem, s. 32.

72 Ibidem, s. 297-312.

73 Ibidem, s. 32. Zob. m.in. M. Gallagher, The Soviet History of World War II, New York 1963; The Russian Version of the Second World War, red. G. Lyons, London 1976; R. Davies, Soviet History in the Gorbachev Revolution, Bloomington 1989.

74 „Stalinizm i nazizm. Porównanie dyktatur”, s. 351-379. 
tencjonalistów" i „strukturalistów”, chociaż w analizach rosyjskich dominuje ujęcie przede wszystkim personalistyczne ${ }^{75}$. Rewizjoniści podkreślali różnice między „pozytywnym” Leninem a dyktatorskim Stalinem, który miał odrzucić idee prawdziwej rewolucji socjalistycznej ${ }^{76}$. Idee powrotu do autentycznej „demokracji socjalistycznej” miały wspomagać reformy ekipy Gorbaczowa. Po 1989 r. w historiografii rosyjskiej rozwijał się już otwarcie nurt negujący dorobek całego okresu bolszewickiej rewolucji, poczynając od okresu rządów Lenina. Von Haagen stwierdził, że rosyjscy „intencjonaliści” zbliżali się do teorii typowych dla szkoły totalitarnej ${ }^{77}$.

Równie interesujące były referaty konferencyjne dotyczące totalitaryzmu nazistowskiego. Georg Steinmetz odniósł się w swoim wystąpieniu do tradycyjnych powojennych sporów historycznych prowadzonych w kwestii ,wyjątkowości" rozwoju historycznego Niemiec w XIX i XX wieku ${ }^{78}$. W jego opinii zwolennicy i krytycy tej teorii (m.in. W. Mc Govern, H. Kohn, H. Wehler, D. Blackbourn, G. Eley, I. Kershaw) dokonywali błędnej oceny procesów rozwoju społecznego ${ }^{79}$. Teza o „wyjątkowości” niemieckiego procesu historycznego została wprawdzie zdyskredytowana w dyskursie akademickim, ale nadal jest przydatna do legitymizowania powojennego ustroju konstytucyjnego RFN ${ }^{80}$.

Hans Mommsen zaprezentował „strukturalistyczne” tezy o nieusuwalnej sprzeczności i autodestrukcyjności reżimu hitlerowskiego, co miało wynikać (podobnie jak w ZSRR) ze stałego napięcia między despotycznym władcą a rozbudowaną strukturą biurokracji państwowej ${ }^{81}$. Ekspansjonizm zewnętrzny III Rzeszy był równoległy z procesem dezintegracji jej aparatu państwowo-administracyjnego. Hitler nie zajmował się administrowaniem państwa na rzecz tworzenia przede wszystkim ,geopolitycznych” teorii ekspansji światowej ${ }^{82}$. Nazizm okazał się wyłącznie niszczycielską siłą destrukcyjną ${ }^{83}$.

Ian Kershaw wskazywał na podobieństwa i różnice między dyktaturą Hitlera i Stalina ${ }^{84}$. Władza Hitlera miała mieć charakter charyzmatyczny

75 Ibidem, s. 36.

76 Ibidem, s. 361.

77 Ibidem, s. 369.

78 Ibidem, s. 313-340.

79 Ibidem, s. 34. Np. W. Mc Govern, From Luther to Hitler, Boston 1941; H. Kohn, The Mind of Germany, New York 1960; G. Eley, From Unification to Nazism, Boston 1986.

80 „Stalinizm i nazizm. Porównanie dyktatur”, s. 34. Zob. ponadto R. Dahrendorf, Deutscher Sonderweg - Mythos Oder Realität?, München 1982; H. Olszewski, The „, German Road” Ideology in Historiography, „Polish Western Affairs”, 1986, nr 2, s. 219-239; H. Grebing, Der „Deutsche Sonderweg" in Europa 1806-1945, Stuttgart 1986.

81 „Stalinizm i nazizm. Porównanie dyktatur”, s. 101-115.

82 J. Stern, The Fuhrer and the People, London 1975; The Shaping of the Nazi State, red. P. Stachura, London 1978.

83 „Stalinizm i nazizm. Porównanie dyktatur”, s. 114-115.

84 Ibidem, s. 117-139. 
i niebiurokratyczny, w przeciwieństwie do dyktatury Stalina, opartej przede wszystkim na strukturach partyjnych ${ }^{85}$. Mit Hitlera był związany wyłącznie z jego osobą, a kult Stalina był wiązany z całym procesem rewolucji bolszewickiej, co umożliwiało dalsze trwanie ZSRR po jego śmierci ${ }^{86}$.

W zamykającym tom tekście Ian Kershaw i Moshe Lewin skupili się na zanalizowaniu reżimów totalitarnych w kontekście pojęcia procesu modernizacji społecznej, trwającego w Niemczech i Rosji od XIX wieku ${ }^{87}$. Niemcy miały stworzyć nowoczesne państwo, ale ze „starym” konserwatywnym (w istocie antymodernizacyjnym i antydemokratycznym) społeczeństwem ${ }^{88}$. Reżim Hitlera nie był reżimem modernizacyjnym, jego celem było bowiem przede wszystkim odrodzenie „ducha narodowego"89. Państwo sowieckie miało natomiast na celu modernizowanie społeczeństwa i gospodarki za cenę totalnego ograniczenia wolności obywatelskich. W ocenie autorów tekstu Hitler i Stalin mogli liczyć na pewne poparcie wybranych grup społecznych w swoich dyktaturach ${ }^{90}$. Oba reżimy miały również ostatecznie charakter autodestrukcyjny.

Omawiana praca ukazuje interesujące nurty historiografii zachodniej aktualne w pierwszym okresie po upadku komunizmu w Europie Wschodniej. W poszczególnych referatach zaprezentowano wątki dotyczące polityki, życia społecznego, ekonomii i ideologii, które winny stanowić przedmiot wnikliwych badań w ramach studiów nad totalitaryzmem. W wielu tekstach podkreślano analogie i różnice między nazizmem a stalinizmem, co dowodzi sporej przydatności zastosowania metody porównawczej w analizowaniu istoty totalitaryzmu. Literatura dotycząca nazizmu może być z pewnością przydatna do badania stalinizmu, co uwidacznia się szczególnie w zastosowaniu teorii „,intencjonalistów” i „strukturalistów” do definiowania istoty ZSRR i dyktatury stalinowskiej.

Rewizjoniści sowietologiczni (w tym m.in. sam M. Lewin) upatrywali istoty stalinizmu w patologicznej osobowości samego Stalina, co jednak nie jest wystarczające dla wyjaśnienia fenomenu jego aktywności polityczneje1. Należy podzielić stanowisko sowietologicznej szkoły totalitarnej oraz wielu filozofów-marksologów (m.in. J. Bocheńskiego, L. Kołakowskiego i A. Walickiego), podkreślających prototalitarny charakter rewolucji bolszewickiej

85 Ibidem, s. 138-139.

86 Ibidem, s. 119-121.

87 Ibidem, s. 419-437.

88 Ibidem, s. 423.

89 Ibidem, s. 424-425.

90 Ibidem, s. 430.

91 M.in. M. Lewin, Lenin's Last Struggle, New York 1968; idem, The Making of the Stalinist System, New York 1985; idem, Stalinism and the Seeds of Soviet Reforms, Armonk 1991; idem, Russia - USRR - Russia: the drive and drift of a superstate, New York 1995; idem, The Soviet century, New York 2005; Stalinism, red. R. Tucker, New York 1977. 
praktycznie od samego 1917 r. Miał on wynikać z jądra doktryny leninizmu, zakładającej prowadzenie rewolucji poprzez dążenie do maksymalnej kontroli nad społeczeństwem i gospodarką, co wymagało stosowania masowej inwigilacji, cenzury i terroru. Nie jest zatem prawdą, że Lenin dążył do pluralistycznej „demokracji socjalistycznej” (czego miała dowodzić np. NEP), gdyż był on zwolennikiem totalitaryzmu, a Stalin był w tej kwestii jego kontynuatorem. W tym zakresie istotne jest zatem podejście „strukturalistyczne” do stalinizmu, które jego bazy upatruje w określonym kształcie instytucjonalno-ustrojowym państwa bolszewickiego stworzonego już przez Lenina ${ }^{92}$.

Badania porównawcze w zakresie totalitaryzmu sowieckiego i niemieckiego winny być prowadzone w ramach historii politycznej, ale również szeroko rozumianej historii społeczno-ekonomicznej ${ }^{93}$. Należy bowiem zanalizować poziom rzeczywistego poparcia dla obu niedemokratycznych reżimów. Obok szerokich mas społecznych poddanych terrorowi istniały również wybrane grupy kooperujące $\mathrm{z}$ władzą totalitarną, nieograniczone jedynie do partii, administracji, sił zbrojnych i aparatu propagandy.

Reżimy Hitlera i Stalina były najbardziej zbliżone do idealnego modelu totalitarnego. Mimo wielu różnic miały niewątpliwie istotne cechy wspólne. Były to jednoosobowe dyktatury odrzucające dotychczasowy porządek ustrojowo-prawny w imię rewolucji i „wyższych praw historii”. Od 1953 r. ZSRR stawał się natomiast państwem biurokracji komunistycznej rządzonym oligarchicznie przez elity partyjne. Podstawą systemu hitlerowskiego i stalinowskiego były masowe partie zintegrowane jedyną oficjalną ideologią kreującą wroga wewnętrznego i zewnętrznego (byli nim Żydzi, Słowianie, kułacy, burżuazja itd.). Ideologie totalitarne miały charakter holistyczny, utopijny ${ }^{94}$.

92 L. Schapiro, The Origin of the Communist Autocracy, Cambridge 1955.

${ }^{93}$ Np. S. Fitzpatrick, Education and Social Mobility in the Soviet Union 1921-1934, Cambridge 1979; D. Rowny, Transition to Technocracy: The Structural Origins of the Soviet Administrative State, Ithaca 1989; Social Dimensions of Soviet Industrialization, red. W. Rosenberg, L. Siegelbaum, Bloomington 1993.

${ }^{94}$ Zob. m.in. R. Griffin, The Nature of Fascism, London 1991; J. Bocheński, Der Sowjetrussische dialektische Materialismus (Diamat), Bern 1960; Handbook on Communism, red. J. Bocheński, G. Niemeyer, New York 1962; J. Bocheński, The Dogmatic Principles of Soviet Philosophy, Dordrecht 1963; idem, Soviet Philosophy: Past, Present and Prospects for the Future, „Natural Law Forum", 1963, nr 21; idem, Guide to Marxist Philosophy, Chicago 1972; idem, Marxsismus-Leninismus, München 1974; idem, Lewica, religia, sowietologia, Warszawa 1996; idem, Marksizmleninizm. Nauka czy wiara?, Komorów 1999; G. Wetter, Der dialektische Materialismus, Fryburg 1960; I. Fetscher, Von Marx zur Sowjetideologie, Frankfurt 1972; H. Ingensand, Die Ideologie des Sowjetkommunismus, Hanower-Brema 1966; G. Lange, Marxismus-Leninismus-Stalinismus, Stuttgart 1957; F. Lowenthal, Das kommunistische Experiment. Theorie und Praxis des Marxismus-Leninismus, Kolonia 1957; A. Meyer, Marxism. The Unity of Theory and Practice, Cambridge 1954; idem, Leninism, Cambridge 1957; idem, Communism, New York 1984; S. Hook, Marx and the Marxists, New York 1965; G. Lichtheim, Marxism. A Historical and Critical Study, New York 1961; J. Plamenatz, German Marxism and Russian Communism, London 1954; R. De George, Patterns of Soviet Thought. The Origins and Development of Dialectical and Historical Materialism, 
Miały usprawiedliwiać masowe stosowanie terroru wewnętrznego oraz ekspansję zagraniczną. Imperializm totalitarny wspierał się na tradycjach niemieckiej geopolityki i rosyjskich carów ${ }^{95}$. W obu reżimach dążono również do przejęcia pełnej kontroli nad świadomością obywatelską poprzez masową propagandę ideologiczną, cenzurę i kontrolę nad sztuką. Oba państwa odrzucały chrześcijaństwo i tradycyjną kulturę europejską, walcząc z liberalizmem, konserwatyzmem, socjalizmem demokratycznym, modelem konstytucyjnej republiki parlamentarnej akcentującej wolności i prawa obywatelskie. Obie dyktatury wchodziły też w konflikty z biurokracją państwową, co prowadziło od osłabienia ich siły politycznej, czy nawet do pełnej autodestrukcji (jak w przypadku III Rzeszy).

Hitleryzm i stalinizm miały też specyficzne cechy systemów quasi-religijnych, na co zwracało uwagę wielu sowietologów (np. J. Bocheński, W. Gurian). Obiecywały wizje udoskonalenia życia poprzez stworzenie utopijnych systemów „czystości rasowej” czy pełnego komunizmu ${ }^{96}$. Wódz przyjmował cechy boskie, ustalając dogmaty ideologiczne w swoistych „katechizmach”. Partia była postrzegana jako quasi-Kościół strzegący ideologicznej ortodoksji, walczący z heretykami, rewizjonistami itd.

Między nazizmem a stalinizmem istniały oczywiście również liczne różnice. Istnienie III Rzeszy było bezpośrednio związane niemal wyłącznie z osobą A. Hitlera, natomiast ZSRR przeżył śmierć Stalina, chociaż oczywiście za cenę określonej „detotalitaryzacji” (co podkreślał m.in. A. Walicki). Od 1953 r. państwem tym kierowała oligarchia partyjna prowadząc rządy „reformatorskie" (Chruszczow, Gorbaczow) albo otwarcie konserwatywne (Breż-

Ann Arbor 1966; idem, The New Marxism. Soviet and European Marxism since 1956, New York 1968; Lenin: the Man, the Theorist, the Leader, red. L. Schapiro, P. Redaway, New York 1967; A. Arndt, Lenin, Politik und Philosophie, Bochum 1982; Contemporary Marxism, Dordrecht 1984; Y. Glazov, The Russian Mind Since Stalin's Death, Dordrecht 1985; J. Scanlan, Marxism in the USRR, Ithaca 1985; L. Haimson, The Russian Marxists and the Origins of Bolshevism, Cambridge 1955; H. Marcuse, Soviet Marxism, New York 1958; D. Bell, Marxism-Leninism: a Doctrine of the Defensive, New York 1966; Soviet Communism and the Socialist Vision, New Brunswick 1972; R. Hunt, The Political Ideas of Marx and Engels, Pittsburgh 1974; J. Gilison, The Soviet Image of Utopia, Baltimore-London 1975; Z. Bauman, Socialism. The Active Utopia, London 1976; L. Colletti, Marxismus und Dialektik, Frankfurt 1977; Sozialismus in Theorie und Praxis, West Berlin 1978; Storia del Marxismo, red. G. Einand i, Torino 1979; D. Mc Lellan, Marxism after Marx, London 1979; S. Moore, Marx on the Choice Between Socialism and Communism, Cambridge 1980; J. Billington, Fire in the Minds of Men. Origins of the Revolutionary Faith, London 1980; Modern Interpretations of Marx, red. T. Bottomore, Oxford 1981; D. Lane, Leninism. A Sociological Interpretation, Cambridge 1981; T. Bottomore, Modern Interpretations of Marx, Oxford 1981; D. Colas, Le leninisme, Paris 1982; N. Harding, Lenin's Political Thought, Atlantic Highlands 1983; J. Larrain, Marxism and Ideology, London 1983; E. Nolte, Marxismus und industrielle revolution, Stuttgart 1983; Marx: the First Hundred Years, red. D. Mc Lellan, Oxford 1983; A. Wright, Socialisms. Theories and Practices, Oxford 1986; T. Kondratiewa, Bolheviks et Jacobins, Paris 1989.

95 W. Smith, The Ideological Origins of Nazi Imperialism, Oxford 1986.

96 M. Burleigh, W. Wipperman, The Racial State. Germany 1933-1945, Cambridge 1991. 
niew). ZSRR upadł ostatecznie na przełomie lat osiemdziesiątych i dziewięćdziesiątych i to nie na skutek nacisków zewnętrznych, tylko przede wszystkim z powodu autodestrukcji własnego systemu polityczno-ekonomicznego.

W ideologii hitlerowskiej głównym wrogiem były grupy obce rasowo czy etnicznie, natomiast komunizm zwalczał przede wszystkim ,reakcyjne” klasy społeczne (kułacy, burżuazja, niepokorna inteligencja itd.). W ramach NSDAP nie dopuszczano praktycznie do jakichkolwiek dyskusji ideologicznych, natomiast pewne frakcje były względnie tolerowane w ramach KPZR, szczególnie w okresie rządów Chruszczowa.

Bolszewicy atakowali wszelkie koncepcje zachowania własności prywatnej, naciskając na nacjonalizację przemysłu i kolektywizację rolnictwa. Ich głównym postulatem była totalna kontrola gospodarki przez państwo. W ramach III Rzeszy kontrola tego typu była zdecydowanie mniejsza, tolerowano istnienie określonych rodzajów własności prywatnej.

Genetycznie bolszewizm i komunizm sowiecki wyprzedzały oczywiście powstanie nazizmu. Wielu badaczy podkreślało wpływ doktryny Lenina na powstanie ideologii hitlerowskiej (m.in. R. Pipes, A. Besancon). M. Kellogg postawił nawet ostatnio tezę, że za powstanie nazizmu odpowiadali nacjonaliści niemieccy i antybolszewiccy emigranci rosyjscy, którzy mieli współtworzyć koncepcje walki z komunizmem sowieckim ${ }^{97}$. Hitler i Stalin inspirowali się wzajemnie m.in. w zakresie stosowanych technik masowej propagandy i terroru (obozy koncentracyjne, obozy pracy). Współpracowali ze sobą w zakresie politycznym, gospodarczym i militarnym (czego symbolem był pakt Ribbentrop-Mołotow), a dopiero po 1941 r. doszło do radykalnego starcia między ich dyktaturami. Po pokonaniu Hitlera w 1945 r. Stalin chciał uchodzić za moralnego pogromcę i uprawnionego krytyka nazizmu, jednak kraje zachodnie w okresie zimnej wojny konsekwentnie uznawały go zasadnie za radykalnego przywódcę totalitarnego, winnego zbrodni porównywalnych do przestępstw nazistowskich.

Badania nad totalitaryzmem są nadal aktualne, ze względu na wzrastające zagrożenie płynące ze strony różnych fundamentalizmów i nurtów autorytarnych wobec zachodnich demokracji liberalno-parlamentarnych. Wiele doktryn niedemokratycznych nawiązuje do wybranych elementów ustroju totalitarnego w zakresie modelu władzy dyktatorskiej (jednostki lub elity politycznej), proreżimowej partii podporządkowanej jedynej „słusznej” ideologii, kontroli społeczeństwa w kwestii mediów czy sztuki, ograniczana prawa i wolności obywatelskich. 